\title{
Structural behaviour of reinforced palm kernel shell foamed concrete beams
}

\author{
U.J. Alengaram \\ SEGi University College, Malaysia \\ M.Z. Jumaat \& H. Mahmud \\ University of Malaya, Malaysia
}

\begin{abstract}
Experimental results of an investigation conducted to study the structural behaviour of reinforced palm kernel shell foamed concrete (PKSFC) beams prepared using palm kernel shell (PKS) as lightweight aggregates (LWA) are reported. The use of foam in the PKS concrete was to reduce the density of PKS concrete from $1900 \mathrm{~kg} / \mathrm{m}^{3}$ to $1650 \mathrm{~kg} / \mathrm{m}^{3}$ and at the same time to produce grade 20 concrete using mineral admixtures. $10 \%$ silica fume and $5 \%$ class $\mathrm{F}$ fly ash were used as additional and cement replacement materials respectively in PKSFC, but normal weight concrete (NWC) contained none. The test results show that flexural and shear capacities of the PKSFC beams were found close to that of NWC beams. The PKSFC beams exhibited more cracks within the flexural zone and shear cracks in the shear zone than NWC beams. The deflection of PKSFC was found to be higher than that of NWC beams.
\end{abstract}

\section{INTRODUCTION}

\subsection{Use of waste material as lightweight aggregate}

Malaysia being the second largest palm oil producer in the world and has total palm tree planted area coverage of 3.8 million hectares. Every year, the production of palm kernel shell (PKS) as a waste from palm oil industry is approximately 4 million tones. The PKS has the potential to be used as coarse aggregate in concrete. PKS is hard and light and hence it can be utilized to replace conventional coarse aggregate to produce lightweight concrete. These types of waste materials, when properly processed, have shown to be effective as construction material.

\subsection{Lightweight aggregate foamed concrete}

RILEM classifies lightweight concrete (LWC) with compressive strength of $15 \mathrm{~N} / \mathrm{mm}^{2}$ or more as structural grade concrete - class-I, and strength between 3.5 and $15 \mathrm{~N} / \mathrm{mm}^{2}$ as structural and insulating concreteclass-II (FIP 1983). LWC in the form of aerated concrete is either a cement or lime mortar, classified as lightweight concrete in which air-voids are entrapped in the mortar matrix by means of suitable aerating agent (Valore 1954).

The main advantage of aerated concrete is its lightweight, which economizes the design of supporting structures including foundation and walls of lower floors. For cellular concrete the voids may occupy anything from 25 to 80 percent of the total volume. As with conventional concrete, the strength of aerated concrete depends on its density; in addition, water-cement ratio, addition of admixtures and curing conditions also play a role in strength development. LWC in the forms of LWAC and foamed concrete played a dominant role in the development of LWC as useful construction material. However, only very few literatures are available on the properties of concrete containing foamed mortar and LWA. Weighler and Karl (1980) conducted experiments on such concrete that contained light expanded clay aggregates (leca) with foamed mortar. They concluded that the foamed concrete incorporating LWA has lighter density and good thermal insulating property. This was due to the voids created by the foam inside the concrete. Thus, for the concrete tested, they found the density and the compressive strength in the range between 700 to $1200 \mathrm{~kg} / \mathrm{m}^{3}$ and 5 to $30 \mathrm{~N} / \mathrm{mm}^{2}$, respectively. This proved to be structural and insulating concrete. However, further works on using such structural and insulating concrete hadn't been carried out. This necessitates further works on lightweight aggregate foamed concrete. Generally manufactured lightweight aggregates cost more than dense natural/ gravel aggregates. Also, manufactured and natural LWA are not available in Asia and use of such LWA is not common. But studies on the use of organic waste materials such as palm kernel shells (PKS) as lightweight aggregates as construction materials are on the rise in Asia and Africa (Abdullah 1984; Okafor 1988; Basri et al. 1999; Ata et al. 2006). 


\subsection{Objectives}

The objective of this work was to produce palm kernel shell foamed concrete (PKSFC) of grade 20 and to study its structural behaviour with respect to flexure and shear and to compare with that of normal weight concrete (NWC). Two beams one each on PKSFC and NWC were propared for testing in flexure. However, to study the shear behaviour, four beams were prepared. In addition two beams on NWC were also prepared for comparison. The variable in shear test was the shear span to effective depth ratio $(\mathrm{a} / \mathrm{d})$.

\section{MATERIALS}

\subsection{Cement and mineral admixtures}

Ordinary Portland cement conforming to MS 522; Part-1:2003 with specific gravity of 3.10 was used for all mixes in this investigation. $5 \%$ of class $\mathrm{F}$ fly ash (FA) by cement weight was used as cement

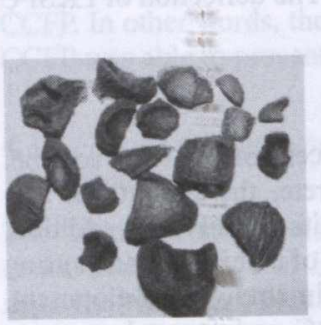

a) Palm kernel shell

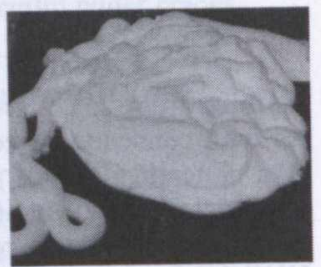

b) Pre-formed foam
Figure 1. Palm kernel shell and foam. replacement. Similarly, $10 \%$ of Silica fume (SF) in undensified form with specific gravity of 2.10 was used as additional cementitious material. The use of SF was to develop a good bond between PKS and the cement matrix.

\subsection{Fine and coarse aggregates}

Mining sand of relative density of 2.7 and of size between 0.15 and $2.36 \mathrm{~mm}$ was used as fine aggregates. The PKS obtained from local crude palm oil producing mill were used as coarse aggregates. Figure 1 (a) shows the shells and it can be seen that they possess curved and irregular surfaces.

\subsection{Foaming agent and superplasticizer}

Synthetic foaming agent (polyoxyethylene alkyl ether tenside) with specific gravity of 1.02 was used in the investigation. It was supplied by BASF, a German based chemical company and diluted in the water in the ratio of $1: 19$ to produce foam. The generated stable foam is shown in Figure 1 (b). The superplasticizer (SP), Rheobuild $1000 \mathrm{M}$ with specific gravity of 1.21 was used at about $0.5 \%$ by cement weight.

\section{SAMPLE PREPARATIONS AND TESTING}

\subsection{Mix proportion and mixing}

The mix design for the PKSFC specimens based on the specific gravities of constituent materials was done. The quantity of foam added was calculated based on the target density of $1650 \mathrm{~kg} / \mathrm{m}^{3}$. However,
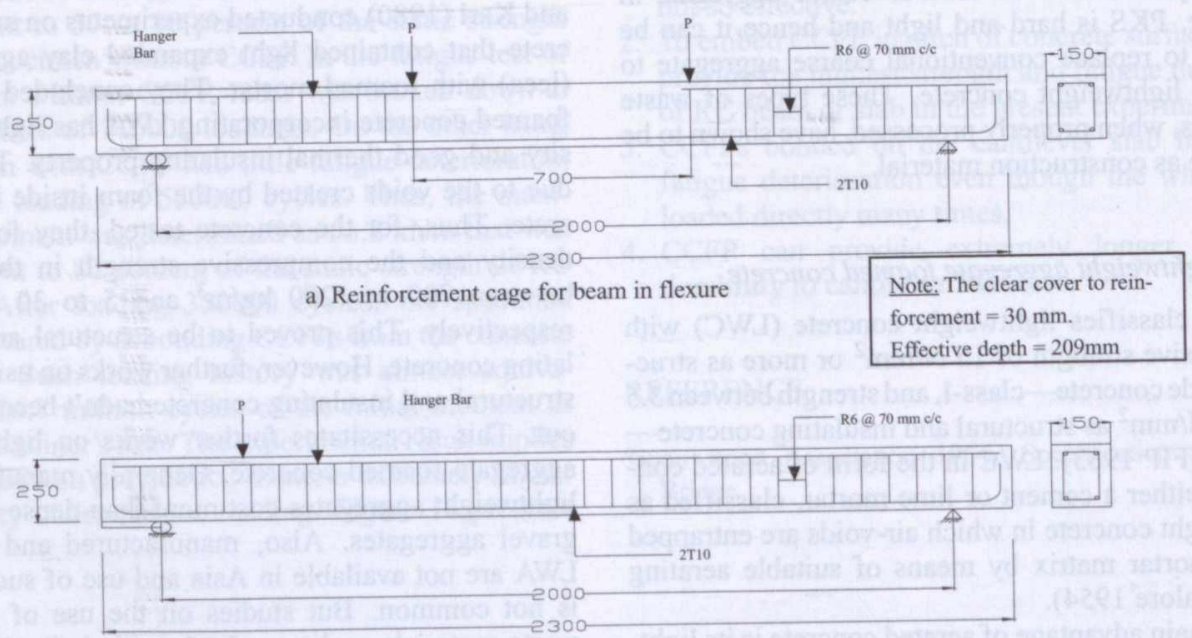

b) Reinforcement cage for beam in shear for $\mathrm{a} / \mathrm{d}=1.0$

(For beams with $\mathrm{a} / \mathrm{d}=2.0$, the link spacing was $150 \mathrm{~mm} \mathrm{c/c}$ )

Figure 2. Reinforcement details of test beams. 
for NWC concrete, the department of environment (DOE) method was adopted. The following mix ratios were used for PKFSC beams: sand to cement ratio $(\mathrm{s} / \mathrm{c})=1.6$; aggregate to cement ratio $(\mathrm{a} / \mathrm{c})=0.8$; water to binder ratio $(\mathrm{w} / \mathrm{b})=0.35$; superplasticizer (SP) content $=$ about $0.5 \%$ by cement weight. The cement content for PKSFC was about $370 \mathrm{~kg} / \mathrm{m}^{3}$. However for NWC, the ratios were in the following order: $\mathrm{s} / \mathrm{c}$ and $\mathrm{a} / \mathrm{c}=3.6 ; \mathrm{w} / \mathrm{c}=0.75 ; \mathrm{SP}=0.5 \%$. Cement content for NWC $=260 \mathrm{~kg} / \mathrm{m}^{3}$. The mixing was done in the following order: firstly PKS in saturated surface dry condition was added with dry sand and mixed in mixer for about 2 minutes. Then one-half of cement and cementitious materials were added and part of water with superplasticizer was added. Then remaining materials were added and mixed.

\subsection{Beam preparation and Instrumentation}

The reinforcement details of beams are shown in Figure 2. It can be seen from the sketch that there was no holding bar provided in the pure moment zone for beams in flexure. For beams in shear, the minimum shear reinforcement was provided based on the $\mathrm{a} / \mathrm{d}$ ratio of 1.0 and 2.0. The clear cover for all beams was $30 \mathrm{~mm}$. Companion concrete specimens were cast to study the mechanical properties of PKSC. Compressive strength of $100 \mathrm{~mm}$ cubes, flexural strength of $100 \times 100 \times 500 \mathrm{~mm}$ prisms and splitting tensile strength on $150 \mathrm{~mm}$ diameter $\times 300 \mathrm{~mm}$ height cylinders have been carried out. All beams designed using BS 8110-Part 1:1997 were cast in steel moulds. They were vibrated using internal vibrator and covered with jute clothes for 28 days and cured. Afterwards the beams were kept under laboratory condition till the day of testing at the age of about 60 days. An Instron machine with a built in capacity of $500 \mathrm{kN}$ load cell was used in testing of beams. The tensile and compressive strains of both reinforcement and concrete were measured through electrical resistance gauges. All the strains were recorded using data logger. In addition, the strain distribution on the vertical face of the beams in the flexural zone was determined using de-mountable digital extensometer with a sensitivity of $0.001 \mathrm{~mm}$. Three linear voltage displacement transducers (LVDT) were placed, one at centre of beams, the other two under load points, to measure the deflections at centre and under load points for beams in flexure. For beams in shear, the vertical deflections were measured under the load single point load was applied for beams tested in shear. However, two-point loads were applied for beams in flexure. All strain, crack width and deflection measurements were measured at every load increment. Table 1 and Table 2, respectively show the details and concrete and steel properties of beams tested in flexure and shear. The beams tested in flexure and shear are designated as FB and $\mathrm{SH}$, respectively. Similarly, the materials are indicated as NWC and PKSFC for normal weight concrete and palm kernel shell foamed concrete, respectively.

\subsection{Properties of PKS}

The natural moisture content and 24 hour water absorption of PKS were determined. The thicknesses and the size of PKS were also measured. The particle size distribution and the specific gravity were determined. The loose and compacted densities were also found. The results of PKS are shown in Table 3.

Table 3. Physical property of palm kernel shells.

\begin{tabular}{ll}
\hline Properties & Values \\
\hline Size $(\mathrm{mm})$ & $2-15$ \\
Thickness $(\mathrm{mm})$ & $1.0-3.0$ \\
Bulk density (loose) $\left(\mathrm{kg} / \mathrm{m}^{3}\right)$ & 568 \\
Bulk density (compacted) $\left(\mathrm{kg} / \mathrm{m}^{3}\right)$ & 620 \\
Specific gravity & 1.27 \\
Water absorption $(1$ hour $)(\%)$ & 12 \\
Water absorption $(24$ hour $)(\%)$ & 25 \\
\hline
\end{tabular}

Table 1. Details of beams tested in flexure and shear.

\begin{tabular}{lllll}
\hline $\begin{array}{l}\text { Beam } \\
\text { designation }\end{array}$ & Material & $\begin{array}{l}\text { Type of } \\
\text { test }\end{array}$ & $\begin{array}{l}\text { No of } \\
\text { beams }\end{array}$ & a/d* \\
\hline FB-P1 & PKSFC & Flexure & 1 & 3.11 \\
FB-N1 & NWC & Flexure & 1 & 3.11 \\
SH-P1 \& P2 & PKSFC & Shear & 2 & 1.0 \\
SH-N1 & NWC & Shear & 1 & 1.0 \\
SH-P3 \& P4 & PKSFC & Shear & 2 & 2.0 \\
SH-N2 & NWC & Shear & 1 & 2.0 \\
\hline
\end{tabular}

\footnotetext{
* Shear span to effect depth ratio.
}

Table 2. Details of concrete properties and reinforcement details (for beams in flexure and shear).

\begin{tabular}{lllllllll}
\hline Material & $\begin{array}{l}\text { Saturated } \\
\text { density } \\
\left(\mathrm{kg} / \mathrm{m}^{3}\right)\end{array}$ & $\begin{array}{l}\text { Slump } \\
(\mathrm{mm})\end{array}$ & $\begin{array}{l}\text { Cube } \\
\text { strength } \\
\left(\mathrm{N} / \mathrm{mm}^{2}\right)\end{array}$ & $\begin{array}{l}\text { Modulus } \\
\text { of rupture } \\
\left(\mathrm{N} / \mathrm{mm}^{2}\right)\end{array}$ & $\begin{array}{l}\text { Young's } \\
\text { modulus } \\
\left(\mathrm{kN} / \mathrm{mm}^{2}\right)\end{array}$ & $\begin{array}{l}\text { Overall } \\
\text { beam } \\
\text { size }(\mathrm{mm})\end{array}$ & $\begin{array}{l}\text { Main bar size }(\mathrm{mm}) \\
\text { yield strength } \\
\left(\mathrm{N} / \mathrm{mm}^{2}\right)\end{array}$ & $\begin{array}{l}\text { Steel ratio, } \\
\rho=\mathrm{As} / \mathrm{bd}(\%)\end{array}$ \\
\hline NWC & 2341 & 76 & 23.78 & 3.44 & 27.0 & $152 \times 251$ & $\begin{array}{l}2 \mathrm{~T}-10 \text { for flexure } \\
\text { and shear; } f_{y}=483\end{array}$ & 0.5 \\
\hline PKSFC & 1675 & 120 & 18.71 & 2.33 & 8.0 & $149 \times 252$ & \\
\hline
\end{tabular}




\section{RESULTS AND DISCUSSION}

\subsection{Mode of failure}

\subsubsection{Beams in flexure}

The flexural behaviour test on two beams, FB-P1 (PKSFC) and FB-N1 (NWC) were conducted using Instron testing machine. A comparison of test results between the PKSFC and the NWC was also made. In order to ensure flexural failure, the shear and compression reinforcement were not provided in the middle-third. The spacing of link was kept at $70 \mathrm{~mm}$ to obtain typical flexural failure. The beams were designed as under-reinforced, so steel bar yields first before the compressive failure occurs in the concrete. In the experiment, both beam shown typical flexural failures as yielding of steel took place followed by concrete crushing at compression zone. Since PKSFC was weaker than NWC, the compression zone of PKSFC had larger crushing area compared to NWC as shown in Figure 3.

\subsubsection{Beams in shear}

For the shear capacity test, the varying shear span (a) to effective depth (d) ratio of, $a / d=1$ and a/d $=2$, was adopted. Three beams for each case have been tested to study the shear behaviour. The spacing of link for beam with $\mathrm{a} / \mathrm{d}=1$ and $\mathrm{a} / \mathrm{d}=2$ has been calculated based on BS 8110: 1997. It has been found from shear testing, thet flexural cracks occur in the beginning followed by shear cracks near the support. The shear cracks start in the shear zone near the support and propagated towards the load point, but ultimately the beams failed in flexure due to the higher shear resistance of the beams. One possible explanation

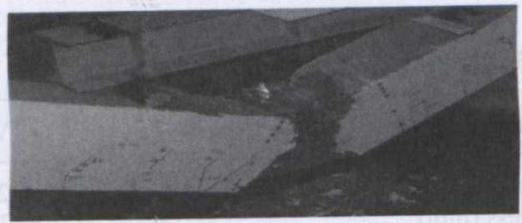

a) PKSFC beam

Figure 3. Flexural failure of beam.

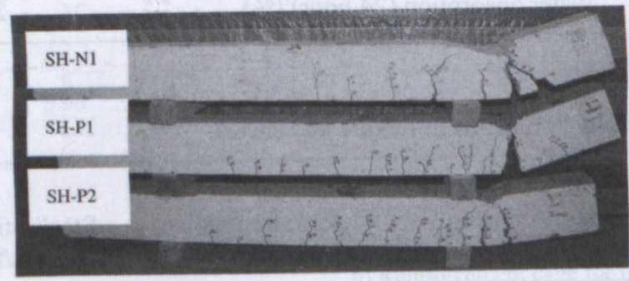

a) Shear crack pattern for $\mathrm{a} / \mathrm{d}=1$ for higher shear resistance could be the aggregate interlock of the PKS that contribute to shear resistance. In addition, the link spacing that was provided based on BS had sufficient shear resistance to prevent shear cracks. The modes of shear failure for beams are shown in Figure 4. The failure of NWC was sudden and brittle in contrast to the ductile failure of the PKSFC. This was the one of the main findings and also an advantage as PKSFC gives adequate warning before failure. As reported by Kong (1995), for shear span to effective depth ratio between 1 and 2 , the shear cracks start independently and not as development of flexural cracks. This was observed in experiments and thus PKSFC and NWC beams behaved similar manner. In shear test, some cracks started as flexural cracks, and then converted into shear crack. Therefore, a lot of cracks, so called flexural-shear cracks occurred. Shear crack was usually propagated faster than flexural crack although the links had been provided to resist it. Thus shear failure behaved in brittle manner compared to that of ductile failure mode of flexural failure.

\subsection{Failure load}

\subsubsection{Beams in flexure}

From Table 4, it can be seen that the first crack load of PKSFC beam, FB-P1 was lower than NWC. This is significant as it was shown earlier that PKSFC had lower modulus of rupture than NWC. In addition, the PKSFC was ductile material as compared to NWC that fails in brittle manner. Ductile behaviour of PKS made PKSFC to behave more elastic than NWC. Therefore, the first crack load of PKSFC was found lower than NWC. However, the number of cracks

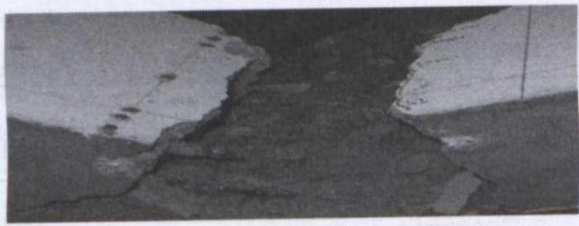

b) NWC beam

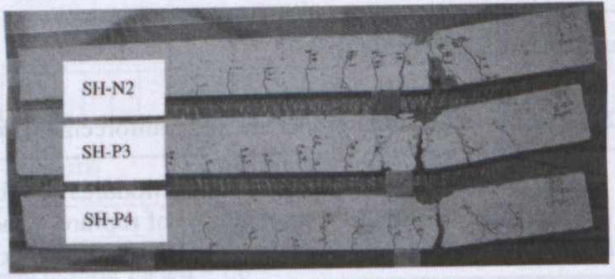

b) Shear crack pattern for $\mathrm{a} / \mathrm{d}=2$

Figure 4. Shear crack patterns for beams in shear. 
Table 4. Results on flexure test.

Ultimate moment, $(\mathrm{kNm})$

\begin{tabular}{|c|c|c|c|c|c|c|c|}
\hline \multirow[b]{3}{*}{ Beam } & \multirow{3}{*}{$\begin{array}{l}\text { First crack } \\
\text { load }(\mathrm{kN})\end{array}$} & \multirow{3}{*}{$\begin{array}{l}\text { Experimental } \\
\text { failure load }(\mathrm{kN})\end{array}$} & \multicolumn{4}{|c|}{ Ultimate moment, $(\mathrm{kNm})$} & \multirow[b]{3}{*}{$\mathrm{M}_{\text {exp }} / \mathrm{M}_{\text {theo(BS }}$} \\
\hline & & & \multirow{2}{*}{$\begin{array}{l}\text { Experimental, } \\
\mathrm{M}_{\exp }\end{array}$} & \multicolumn{3}{|c|}{ Theoretical, $\mathrm{M}_{\text {theo }}$} & \\
\hline & & & & BS & $\mathrm{ACI}$ & EURO & \\
\hline FB-N1 & 2westat & 60.5 & 19.21 & 13.36 & 13.14 & 12.67 & 1.44 \\
\hline FB-P1 & 13 & 58.5 & 18.70 & 13.01 & 12.91 & 12.43 & 1.44 \\
\hline
\end{tabular}

Table 5. Shear capacity $(a / d=1)$.

\begin{tabular}{|c|c|c|c|c|}
\hline \multirow[b]{3}{*}{ Beam } & \multicolumn{4}{|c|}{ Shear capacity, V $(\mathrm{kN})$} \\
\hline & \multicolumn{3}{|c|}{ Theoretical, $\mathrm{V}_{\text {theo }}$} & \multirow{2}{*}{$\begin{array}{l}\text { Experimental, } \\
V_{\text {exp }}\end{array}$} \\
\hline & BS & ACI & EURO & \\
\hline SH-P1 & 60.57 & 68.07 & 61.57 & 78.14 \\
\hline SH-P2 & 60.57 & 66.58 & 57.12 & 70.83 \\
\hline SH-N1 & 71.75 & 73.59 & 68.09 & 92.77 \\
\hline
\end{tabular}

was found more in PKSFC beams than NWC. This consequently resulted in smaller crack widths in PKSFC than NWC beams. The addition of silica fume and fly ash to the PKSFC increased the cohesiveness of the concrete. This enhanced the bond strength which enabled more number of cracks. The failure load and hence the experimental ultimate moment of NWC were higher than PKSFC.

\subsubsection{Beams in shear}

Table 5 shows the comparison between theoretical and experimental shear capacities for beams tested for shear of $a / d=1$. The theoretical shear capacity has been calculated by referring to different design codes such as British Standard (BS), American Code $(\mathrm{ACI})$, and Euro Code (EC). From the results, it can be seen that the experimental shear capacities of all three beams were found higher than the theoretical values. The theoretical calculation is made by assuming the procedure of testing is perfect and no error would occur during testing. Further, the NWC beams recorded higher shear capacities compared to that of PKSFC. The poor adhesion between PKS aggregate and cement matrix and the smooth surface of PKS were some of the factors that affect the compressive strength. Though the addition of SF imparts cohesion to the mix, the formation of foam in the vicinity of PKS makes the bond weaker. Thus, the strength of PKSFC was lower than the NWC. The values of theoretical and experimental of shear capacities for $\mathrm{a} / \mathrm{d}=2$ are shown in Table 6. The results show similar trend as that of $\mathrm{a} / \mathrm{d}=1$, as the experimental value was always higher than theoretical value based on BS code. The comparison for both shear capacity test of $\mathrm{a} / \mathrm{d}=1$
Table 6. Shear capacity $(a / d=2)$.

\begin{tabular}{|c|c|c|c|c|}
\hline \multirow[b]{3}{*}{ Beam } & \multicolumn{4}{|c|}{ Shear capacity, V (kN) } \\
\hline & \multicolumn{3}{|c|}{ Theoretical, $\mathrm{V}_{\text {theo }}$} & \multirow{2}{*}{$\begin{array}{l}\text { Experimental } \\
V_{\text {exp }}\end{array}$} \\
\hline & BS & ACI & EURO & \\
\hline SH-P3 & 34.06 & 41.47 & 40.74 & 40.29 \\
\hline SH-P4 & 34.06 & 42.30 & 41.66 & 41.08 \\
\hline SH-N2 & 40.96 & 47.97 & 48.95 & 47.60 \\
\hline
\end{tabular}

and $\mathrm{a} / \mathrm{d}=2$ shows that the shear capacity for $\mathrm{a} / \mathrm{d}=1$ was higher than the shear capacity for $a / d=2$. This is because the load point for $\mathrm{a} / \mathrm{d}=1$ was nearer to the support, so it has to resist higher load. The ratio of experimental shear capacities between $\mathrm{a} / \mathrm{d}=1$ and $\mathrm{a} / \mathrm{d}=2$ was found as 1.83 and 1.94 , respectively for PKSFC and NWC.

\subsection{Strains of beams in flexure and shear}

Both beams of PKSFC and NWC recorded higher reinforcement strains. The strain at yielding of steel in both beams was close to 3000 microstrains. However, after yielding the PKSFC behaved in ductile manner thus, the final strain before failure was found about 7000 microstrains. As mentioned due to lower modulus of rupture PKSFC beam cracked earlier than NWC beam. Higher steel strain in PKSFC is also an indication that good bonding exists between steel and concrete. In addition, due to the ductile behaviour of PKSFC, the beams undergo higher strain compared to NWC. The maximum steel strain recorded for $\mathrm{a} / \mathrm{d}=2$ was in the range of 2500 to 2780 microstrains. This shows that the reinforcement was close to yielding. Higher compressive strains were recorded for concrete for the PKSFC beam than for the NWC beam soon after the first crack. This was possibly due lower modulus of elasticity of PKSFC as it recorded only $30 \%$ of NWC. Thus, PKSFC beam had undergone larger deflection and resulted in larger concrete strains.

\subsection{Deflection of beams in flexure and shear}

Higher deflections were recorded for beams in flexure compared to beams in shear. The ductility ratio, 


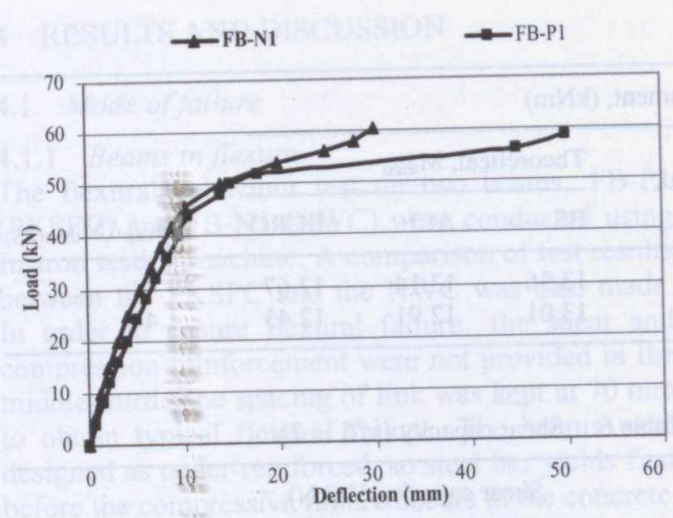

Figure 5. Mid-span deflection of beams in flexure.

Table 7. Deflection of beams in shear $(a / d=2)$.

\begin{tabular}{lllll}
\hline & \multicolumn{3}{l}{ Service deflection under load point (mm) } \\
\cline { 2 - 4 } & \multicolumn{2}{l}{ Theoretical, $\delta_{\text {theo }}$} & & Experimental, \\
\cline { 2 - 4 } Beam & BS & ACI & EURO & $\delta_{\text {exp }}$ \\
\hline SH-P3 & 6.84 & 6.97 & 8.09 & 6.01 \\
SH-P4 & 7.02 & 7.06 & 8.28 & 4.29 \\
SH-N2 & 4.55 & 4.02 & 5.10 & 2.78 \\
\hline
\end{tabular}

defined as the ratio of deflection at yield stage to ultimate stage was found twice for PKSFC beams compared to NWC beam in both flexure and shear. Figure 5 shows the mid-span deflection of beams in flexure.

Table 7 shows the service deflection of beams in shear under the load point for $\mathrm{a} / \mathrm{d}=2.0$. The experimental deflections of PKSFC beams are higher than the NWC beams. Based on the ductility ratio of beams in flexure, it can be concluded that the behaviour of PKSFC beam has higher ductility characteristics than the corresponding NWC beam. The PKSFC will give ample warning before failure and such behaviour is best suited for structures in earthquake prone region.

\section{CONCLUSIONS}

1. The first crack load of PKSFC beams was found to be lower than the corresponding NWC beams.

2. Both the NWC and PKSFC beams failed in typical flexural mode.

3. The experimental flexural capacities of the shear link spacing calculated using BS8110: Part 1: 1997 was sufficient to resist shear crack from widening and prevent the shear failure in PKSFC beams.

4. The higher reinforcement strain recorded for PKSFC beams in flexure shows that the bond between PKS and cement paste is stronger.
5. The lower modulus of elasticity of PKSFC resulted in higher deflection than NWC. However, the deflections at serviceability limit state were within limits.

6. The ductility ratio of PKSFC was higher than NWC, and thus proved the ductile nature of PKSFC.

7. PKSFC beams had more number of crack compared to NWC beams. Thus, the average crack spacing and crack width were found lower in PKSFC beams.

8. Experimental shear capacities generally found higher than theoretical values.

\section{ACKNOWLEDGEMENTS}

This research work is funded by Ministry of Science, Technology and Innovation (MOSTI) under Science Fund Grant no. 03-01-03-SF0309.

\section{REFERENCES}

Abdullah, A.A.A., 1984. Basic Strength Properties of Lightweight Concrete Using Agricultural Wastes as Aggregates, Proceedings of International Conference on Low-cost Housing for Developing Countries, Roorkee, India.

ACI manual of concrete practice, Part 3-2002, American Concrete Institute 2002.

Ata, O., Olanipekun, E.A., Oluola, K.O. A comparative study of concrete properties using coconut shell and palm kernel shell as coarse aggregates. Building and Environment 2006; 41: 297-301.

Basri, H.B., Mannan, M.A., Zain, M.F.M. Concrete using waste oil palm shells as aggregates. Cement and Concrete Research 1999; 29: 619-622.

BS 8110: Part 1:1997. Structural use of concrete. Part 1. Code of practice for design and construction, British Standards Institution 1997.

BS 8110: Part 2:1985. Structural use of concrete. Part 2. Code of practice for special circumstances. British Standards Institution 1985.

Eurocode 2: Design of concrete structures; Part 1 General rules and rules for buildings, 1992.

FIP Manual of Lightweight Aggregate Concrete, 2nd ed. London: Surrey University Press; 1983.

Kong, F.K., Evans, R.H. Reinforced and Prestressed Concrete, 3rd edn. Chapman \& Hall; 1995.

Okafor, F.O. Palm kernel shell as a lightweight aggregate for concrete. Cement and Concrete Research 1988; 18 901-910.

Valore, R.C. Cellular concretes-physical properties. J Am Concr Institute. $1954 ; 25: 817-836$.

Weighler, H., Karl, S. Structural lightweight aggregate concrete with reduced density-lightweight aggregate foamed concrete. International Journal of Lightweight Concrete 1980; 2: 101-104. 